\title{
Filling the Gaps in the Law of Private Limited Companies in Ethiopia: Law, Contract and or Custom
}

\author{
Alemu Balcha Adugna \\ School of Law, Madda Walabu University, Robe, Ethiopia \\ Email address: \\ alexbalcha08@gmail.com \\ To cite this article: \\ Alemu Balcha Adugna. Filling the Gaps in the Law of Private Limited Companies in Ethiopia: Law, Contract and or Custom. Journal of \\ Political Science and International Relations. Vol. 2, No. 3, 2019, pp. 60-67. doi: 10.11648/j.jpsir.20190203.11
}

Received: September 5, 2019; Accepted: September 25, 2019; Published: October 15, 2019

\begin{abstract}
Business people tie themselves under certain form of business organization's chain and tackle commercial hurdles through collective efforts. In Ethiopia, present day witnessed proliferation of tremendous business organizations in all corners of the country. The structure of business organization chosen may, however, have an impact on how simple it is to obtain finances, how taxes are paid, how accounting records are kept, whether liability of members is limited or unlimited and the ways of. Like other forms of business organizations, Private limited company was introduced in Ethiopia in 1960 when the empire of Ethiopia adopted a comprehensive commercial code for the first time. The 1960 Commercial Code of Ethiopia has recognized six forms of business organization from which private limited company is the most popular and prevalent forms of business organization. Per Article 510/2 of the commercial code of Ethiopia, private limited company is a company whose members are liable only to the extent of their contribution. Yet, commercial code have not sufficiently address the issues of capital maintenance, valuation of in kind contribution, administration of paid up capital, shareholders general meeting, liquidation, founders, and expulsion and/or withdrawal of shareholders. Besides, absence of cross reference to provision of law of Share Company is another worst weakness of law of private limited company. This article has unveiled whether filling the gaps via contract, custom or law is possible. Accordingly, contract can solve the conundrums underlying it by inculcating to articles and memorandum of association, and corporate code of conduct. But, since custom on corporate governance is at an infancy stage, it is tricky to recommend customs as a way out. so the best option is to amend laws on private limited companies in a way that address the existing practical problems associated with such companies so as to make the Ethiopian law compatible with the current global affairs.
\end{abstract}

Keywords: Private Limited Company, Contract, Custom, Law

\section{Introduction}

Business Organization is an important scheme that enables people to do business which would be difficult, if not impossible, for them to do alone. Thus in these days business people tie themselves under certain form of business organization's chain and tackle commercial hurdles through collective effort. Companies are the mostly known and frequently operated forms of business organizations. They are also named as 'corporations' [1]. The word corporation is derived from the Latin word 'corpus 'which means body or person [2]. The Black's law Dictionary also defines a corporation as "an entity having authority under law to act as a single person distinct from the shareholders who own it and having rights to issue stock and exist indefinitely... and has the legal powers that its constitution gives it" [3]. Companies are also defined as "an artificial being, invisible, intangible and existing only in contemplation of law" [4]. They are artificial organizations created by the law; are separated from their owners and managers; have their own rights, duties and powers; and have the capacity to exist perpetually [2]. They are business entities owned by individuals or juristic bodies and operate with names different from their owners. They own property, may conclude contract and commit crime. Companies are "the succession or collection of persons having at law an existence, rights and duties, separate and distinct from its members who vary from time to time [5]. In nutshell there is no universally accepted definition for the term Company or corporation as various jurists and writers have approached it from various perspectives.

Companies can be established in forms of private limited companies or share companies. Since, the main concerns of 
my article is private limited company, Share Company is not going to be discussed. Private limited companies are incorporated businesses that set up as legal entities in their own right and exist quite separately from their owners. The owners of private limited companies are called shareholders, because they own a part, or a share, of the company. A private limited company can own property and equipment employ people and borrow money. It also pays corporation tax (an income tax on companies) from the profits of the company as well as the dividends' to be paid to the individual shareholders i.e. economic double taxation [7]. There different types of private limited company around the world. We can mention for example, private limited company by share, private limited by guarantee and unlimited private limited company/type of private limited company whose liability is unlimited. A private company limited by shares means the members'/shareholders/liability is limited to the original value of the shares issued but not paid for. A company is limited by shares when the liabilities of its owners/shareholders/bear do not exceed the monetary value of the shares they hold [6]. Companies limited by guarantee are companies formed on the principle of having the liability of its members limited to the respective amounts that the members guarantee to contribute to the property of the company if it is wound up. This type of company does not have a share capital and its members are guarantors rather than shareholders. A private company limited by guarantee means the company members financially back the company up to a specific amount if things go wrong. Companies limited by guarantee cannot raise finance by issuing/selling shares and therefore do not have a share capital [6].

In Ethiopia, the origin of companies could be traced back to the 1909, where the first Ethiopian private Company was formed in the name of Agricultural and Commercial Development Company. Nevertheless, the first consolidated company law was enacted in 1933, which derived some of its provisions from its predecessor [7]. As old age trends of conducting business on one's own gradually gave way to organized business form, the Imperial government wanted to have a comprehensive and complete law of business organization as a result of which, the 1960 Commercial Code of Ethiopia was brought in to existence. Under Ethiopian law, though there is no definition of a company, it is possible to understand what a company is through its attributes [8]. When we see the Commercial Code, it is hard to find any provision which defines what companies are. However, companies are set up by Partnership Agreements of two or more persons, i.e. in Ethiopian case they need at least five persons to establish share companies and two persons to form private limited companies [9]. The agreement between the partners shall be to join together, to bring in contributions and share losses and profits. Companies are also the association of capital. The Ethiopian Commercial Code provides two forms of companies: Share Company and private limited company. This can inferred from Art. 212 (e) \& (f) of commercial code of Ethiopia [9]. Again, on the basis of article 555-557 of commercial code [9], there are also other businesses organizations incorporated outside Ethiopia in other legal systems and carried out their business, and are regulated with the rules that apply to share company. The two companies in Ethiopia have distinct features as regards formation, ways of raising capital, share transfer, company management, and the like. Private limited company, like other forms of business organizations, was introduced in Ethiopia in 1960 when the Empire of Ethiopia adopted for first times a comprehensive commercial code. But this does not mean that there were no business organizations in Ethiopia prior to the enactment of the commercial code. Even though there were not distinctive types of business organization like the ones recognized under the commercial code with uniform and comprehensive law to regulate them there had been business organizations before the code was adopted. Before the enactment of 1960 civil code there was an Arrangement under which a business is carried on by two or more persons jointly have long existed in Ethiop. As early as the 15 th century the Fetha Negast or "Law of the Kings "devoted an entire chapter [chapter 34] to the regulation of partnership."

In Ethiopia, private limited companies are dramatically increasing in all corners of the country and its role in the economy of the country is also considerable. Private limited company in Ethiopia, however, is surrounded by problems irrespective of its tremendous rising up. The problems are related with the provisions of the commercial code governing private limited company in Ethiopia. The sketchy nature of the provisions in the commercial Code in turn brought about practical problems which are prevailing in every company. The issues of Capital maintenance, expulsion and/or withdrawal of shareholder, manner of administering the paid up capital, grounds for appointment of directors, and valuation of Non-cash contributions are not well regulated. Accordingly, this article will explore whether contract, custom or law could be a panacea solution for solving major gaps of private limited company law of Ethiopia.

The aim of this article is therefore, to examine and assess whether the major gaps of private limited company law of Ethiopia can be filled by contract, custom or law and exploring opportunities for proper regulation. The remaining parts of this article are classified into 4 sections. The second section will uncover general concept of private limited companies in Ethiopia. The third section will present the issues of legal regime on corporate organization and major gaps of laws that regulate private limited company. The fourth section will embark on critically analyzing the issues of filling the Gaps in the Law of Private Limited Companies in Ethiopia by Law, Contract and or Custom. The fifth section finalizes the article by a way of conclusion and recommendation.

\section{General Concept of Private Limited Company in Ethiopia}

\subsection{Nature and Formation of Private Limited Companies}

Private limited company is a company whose members are 
liable only for to the extent of their contributions. It is established by the memorandum of association and article of association. The members are minimum of two and maximum of fifty. The private limited company is managed by the manager (s). It can be established for a limited period of time to accomplish a plan of the company or it could be establish for unlimited period of time. As we can infer from article 510 of Commercial Code Ethiopia, members of the company are fully, jointly and severally liable to the third parties in respect of commitment intended into the formation of the company [9].

Generally the main natures of private limited company in Ethiopia could be summarized as follows; In the first place if look at Article 523 (2), (3) (4) and (5) of commercial code [9]), one of the characteristics of private limited company is that shares are not freely transferable and this is one of the factors that make the companies private. Not only this, from article 510 (3) of commercial code [9], we can understand that Private limited Company does not attract huge amount of capital as there is no public subscription in its formation, and it does not issue transferable securities in any form. It also combines the advantages of partnerships and Share Companies with a very flexible internal structure in that like partnership, the relationship among members must be one of trust, confidence and absolute loyalty if the enterprise is to succeed. In view of this though private limited company are association of capital it resembles that of partnerships where personality is crucial.

On the other hand, like a share company, a private limited company enjoys the benefit of limited liability and allows business people to avoid the threat of untimely dissolution inherent in partnerships. This implies that private limited company is a distinct legal person that may enjoy the benefit of perpetual life of companies or continuity of life [7]. The corporate nature of private limited company entitles the same a limited liability by separating assets of the company from that of its members. This means investors in the private limited company are not liable for the debts of the company more than the amount they contribute pursuant to Article 510 (1) of the Commercial Code [9].

Article 525 and 526 of commercial code [9] provides that private limited company shall be managed by one or more managers who may be members or non-members Unlike Share Company, the law does not expressly require to have a board of directors as a governance organ in private limited company. Thus, private limited company avoids the need to provide for certain corporate formalities, among others, it could be managed by the shareholders of the company rather than the board of directors [7].

The formation and the management of Private Limited Companies are rightly different from country to country, its characteristics such as limitation of membership, minimum share capital, are not identical throughout the world. In the context of our country from article 510 (1) (2) of commercial code [9], Unlike Share Company that requires the minimum of 5 person, formation of Private Limited Companies requires at least two persons and a maximum of fifty members. What is more, on the basis of article 512 (1) and 517 (g) of commercial code [9], a person who decides to form a Private Limited Companies must raise at least 15,000 Ethiopian dollars as a minimum capital, which shall have to be fully paid up, and be shown in the memorandum of association. As opposed to the share company, the law does not impose any obligation on the members of a Private Limited Companies to deposit the capital contributed.

\subsection{Management and Dissolution of Private Limited Companies}

As we can infer from article 525 of commercial code [9], a private limited company is managed by one or more managers while Share Company is managed by one or more managers and directors whose minimum number shall be three. Unlike a share company, a private limited company does not have a board of directors or managers chosen by the board. A private limited company is managed by its shareholders or some of them like a partnership. In Ethiopian private limited company shareholders meeting is based on the numbers of shareholders to the company. From article 525 and 532 of commercial code [9], it is clear that Shareholders' meeting is not necessary when the shareholders are below twenty and resolutions or decisions can be made by managers saving for change of nationality and modification of articles of association of the company. More over even if the Commercial Code makes shareholders meeting as one governing body when members are above twenty, the type of meeting/either general or special meeting/is not clearly set.

The 1960 Commercial Code of Ethiopia makes auditors one of the mandatory statutory governance bodies in the corporate governance structure and system of Share Companies. However, when we come to private limited companies, the Commercial Code puts auditors as one of the mandatory governance body when the number of shareholders is not below twenty. When the number of shareholders that form the private limited company is more than twenty the company is obliged to have or appoint at least three auditors.

Dissolution is the process of terminating the legal existence of business organization or it is end of the legal existence of artificial persons. The grounds for dissolution of the Private Limited Companies can be summarized as follows. Accordingly, dissolution of private limited company can be by Act of parties (members). Members of companies may decide to avoid their company. Where the life of span of a company was not limited by a formative document, member of the company can dissolve the company at any time. But, on the basis of article 495 (d) of commercial code [9] for dissolving a company, there should be a resolution of an extraordinary general meeting.

Another ground for the dissolution of private limited company is Dissolution by operation of law: According to article 542 (2) of commercial code [9] "A judicial interdiction, bankruptcy or insolvency of a member, shall not cause dissolution of a company nor shall death of a member unless otherwise expressly provided in the articles of association." Thus, where a member dies, unless article or other documents 
of a company envisages (possible) otherwise, heirs may be assumed as members of the company. Hence, when articles of association provided for dissolution of private limited company judicial interdiction, bankruptcy or insolvency of a member or death of a member can leads to dissolution of private limited company. Not only this, failure or accomplishment of business purpose may leads to dissolution of private limited companies. According to article 217 of commercial code [9], "any business organization shall be dissolved where its purpose has been achieved or cannot be achieved".

Finally, private limited companies may dissolved by court. According to article 218 of the commercial code [9] the court is entitled to order dissolution. Sub article 2 provides that there shall be good because in particular where a particular seriously fails in his duties or becomes through infirmity or payment illness or for any other reason incapable of carrying out his duties or where serious disagreement exists between the parties.

\section{Legal Regime on Private Limited Company of Ethiopia and Its Major Gaps}

\subsection{Legal Regime on Corporate Organization in Case of Ethiopia}

\subsubsection{Ethiopian Commercial Code of 1960}

Corporate governance in Ethiopia emerged following the promulgation of the Commercial Code in 1960. Corporate governance in Ethiopia is regulated by Book II, Chapter 4 (Arts. 347-428) of Title VI of Book II of the Commercial Code [9]. Therefore, the major law that governs the establishment, operation and winding up of corporate organizations in Ethiopia is the 1960's Commercial Code of Ethiopia or simply Commercial Code.

\subsubsection{Special Laws}

In addition to the Commercial code, various Proclamations, Regulations, Directives, Codes, Memorandum and articles of Associations, procedures and guidelines have been issued by legislators, regulators, board of directors and management of the share company at different times to cope up with the political, economic and social development of the global, national and specific conditions at company level. Accordingly, Ethiopian Parliament has enacted Proclamations No. 592/2008 [10] to provide for banking business which empowers National Bank of Ethiopia to regulate the financial sector and the ability to issue directives and accordingly the National Bank of Ethiopia has issued 61 directives up to 2014 for banking business only. Insurance Companies by Proclamation No. 746/2012 [11], Micro Finance Institutions by Proclamation No. 626/2009 [12], and Public Enterprises are governed by Proclamation No. 25/1992 [13]. Hiring, managing, occupational Safety, Health and Working Environment, and firing of human resources of share companies are governed by Labor Law, Proclamation No.
377/2003 (as amended) [14]. Ethiopia has also promulgated a Proclamation on Trade Competition and Consumers Protection No. 813/2013 [15] which shall apply to any commercial activity or transaction in goods or services conducted or having effect within the Federal Democratic Republic of Ethiopia. To conclude this part, the Ethiopian legal regime governing corporate governance is basically incorporated under the Commercial Code and special laws discussed above. Apart from these legislations, other laws such as the investment law, business registration law, are also highly importance in this field. Those aforementioned regimes would equally applied in case of private limited company saving for those regimes on certain undertaking like insurance and banking on which private limited company is not allowed to invest.

\subsection{Major Gaps of Law of Private Limited Company of Ethiopia}

In Ethiopia, private limited companies are dramatically increasing in all corners of the country and its role in the economy of the country is also considerable. Private limited company in Ethiopia, however, is surrounded by problems irrespective of its tremendous rising up. The problems are related with the provisions of the commercial code governing private limited company in Ethiopia. The sketchy nature of the provisions in the commercial Code in turn brought about practical problems which are prevailing in every company. Accordingly, the main gaps of law of private limited companies include the following;

a) Provision governing shareholders general meeting is not also clear. This can be inferred from article 525,532 and 533 of commercial code [9]. Accordingly, the issues as to whether rules on convocation, procedures and validity requirements for share company meetings are applicable in case of private limited company is cumbersome. not only this, Even if the Commercial Code makes shareholders meeting as one governing body when members are above twenty, the type of meeting/either general or special meeting/is not clearly set.

b) Besides, in relation to Non-cash contributions, the issues of valuation have left for shareholders to determine by agreement. That means, unlike the elaborate procedures set forth in Article 315 of commercial code [9] for determining the value of a contribution in kind to a share company, Article 519 of commercial code [9] requires the members of a private limited company to determine the method of valuation and the value of the contribution [10]. Does this mean the members should value it? It is quite cumbersome.

c) Unlike that of a Share Company, no provision of the Commercial Code Pertaining to a Private Limited Company deals with the manner of administering the paid up capital. In Ethiopian law, members of private limited companies are expected to pay their contributions in lump sum or fully pursuant to Art. 517 (g) of the Commercial Code [9]. That means if the 
capital is not fully paid up no private limited company would be formed. Beyond this there is no clear provision that vehemently address the issues of administration of paid up capital. From the inception, provisions of the Commercial Code dealing with the private limited company have no clear stipulation as to the full payment of capital before the formation of a Private Limited Company. In Share Companies the law explicitly provides that capital of a company shall be fully subscribed and one quarter of such capital at least be paid up and deposited in a bank in the name of the company. However, provisions dealing with Private Limited Company fail to provide such requirements plainly. In this regard, the law in Ethiopia simply requires a statement that the capital is fully paid up to be shown in the memorandum of association [6]. Even, sometimes it stated in the memorandum of associations is simply for the sake of formalities that have to be fulfilled to get the company registered.

d) In the Commercial Code of Ethiopia, provisions dealing with Private Limited Company offer members of a company with a limited liability. The provisions under Art. 510 (1) of the Code [9] do not explicitly provide about the liability of members and their companies compared to that of share companies. Further, the law does not explicitly deal with the distinctions of the two companies as far as limited liability is concerned. As a result, the very provision leads to different interpretations and becomes the source of litigation [6].

e) Private limited companies may not step in to legal existence without certain arrangement. Thus, it is beyond dispute that Private Limited Company comes in to being through certain promotional activities of founders. On the contrary, provisions dealing with Private Limited Company do not stipulates about the issue of founders as opposed to that of share companies [6].

f) As far as company governance is concerned, provisions dealing with private limited company neither prohibit nor expressly authorize such companies to appoint Board of Directors. In practice, there are some private limited companies which have appointed Board of Directors. But, the issue as to grounds for appointment of directors and the like has not inculcated in the provision governing private limited companies [6].

g) Capital maintenance has a prominent role in securing the creditors and ensuring the sustainability of private limited companies. But, Ethiopian law of private limited companies has no detailed capital maintenance provisions.

h) Again, the issue as expulsion and/or withdrawal of shareholders has not clearly addressed.

i) What is more, the Commercial Code does not provide for provisions that govern liquidation of Private Limited Company though liquidation is an inevitable fact in
Private Limited Company.

\section{Filling the Gaps in the Law of Private Limited Companies in Ethiopia: Law, Contract and or Custom}

\subsection{Filling the Gaps of Law of Ethiopian Private Limited Company by Law}

There various governing laws in relation to private limited companies in case of our country. But, the existing law is not sufficiently addressed every issues in relation to private limited company. Prominently, the main governing laws on companies or business organization in case of our country (commercial code) have not sufficiently addressed some of the issues in relation to private limited company. The Ethiopian Commercial Code has to be amended putting into consideration a wide array of points. The law has to be drafted to enable businesses create jobs, prosperity and make innovations easy to compete in the global village" [16]. The Ethiopian Commercial Code is 58 years old and there are some reports that the commercial code is being revised. Out of the 58 years the code was suspended between 1975 and 1991 during a blanket nationalization of the economy by the leftist military government [16].

The world has changed. There are virtual companies, digital currencies, and electronic contracts, digital signatures, data protection, e-commerce, angel investors, venture capitals, and private equity firms, Limited Liability Partnership (LLP) etc. Hence, it is important to list shortcomings of the 1960 commercial law to propose solutions to enable businesses compete in the $21^{\text {st }}$ century global economy [16]. Achieving this aim will not be an easy task and it needs a lot of able lawmakers with a broader view of the world and in-depth intellectual capital. The commercial code of Ethiopia was drafted in 1960 long before many of the financial innovations and technologies. By the virtue of its age it has many limitations to govern the $21^{\text {st }}$ century commercial transactions through the real and virtual world [16]. From the aforementioned facts, it is clear that the Ethiopian commercial code that lasts more than an half of a century cannot govern commercial transaction of $21^{\text {st }}$ century and it should be amended. Hence, filling the gaps either by amending the existing commercial code by inculcating every aspects of current commercial aspects and necessary provision for filling the aforementioned gaps of private limited company law or coming up with new proclamations, directives is of essence. On other hand, though I did not manage to get a copy of the revised draft, the revision of the code has to be done with sole purpose of enabling businesses to flourish and creating prosperity by inculcating necessary provision that exactly fulfills the gaps of commercial code in general and private limited company law in particular.

\subsection{Filling the Gaps of Law of Ethiopian Private Limited Company by Contract}

Contract is simply defined as an agreement that is 
enforceable in law [17]. In case of our country if we look at article 1675 of civil code [18], Contract is "an agreement whereby two or more persons as between themselves create, vary or extinguish obligations of a proprietary nature". A contract is considered as one form of juridical act. The concept of juridical act is introduced to distinguish between ordinary physical acts and those acts that have legal effects. A juridical act is one that is enforceable in law or that creates legal rights and obligations [17].

When we come to the formation of contract, it involves the criteria that the state uses in order to determine whether or not it has to execute agreements of persons between themselves. In other words, the state uses the following yardsticks to check whether or not persons have made a law that binds them. Accordingly, on the basis of article 1678 of civil code [18] capacity, consent, object, and form, if any are the prominent yardstick for the formation of valid contract. All contract involve the element of capacity, consent and object i.e. contract cannot be imagined without capacity, consent, and object. However, if we see article1723 of civil code [18], form is required for few contracts only. The law of contracts governs the commercial relationships between parties, typically buyers and sellers of goods, services, and rights. Though, the Law of Obligations in the 1960 Civil Code [18] in Ethiopia is comprehensive, most of the other components critical to an efficient culture of commercial contracts are either nonexistent or seriously underdeveloped [17]. Whatever it may be, contract that fulfilled necessary requirement can govern the companies. The prominent contract and corporate code of conduct as a governing regime in corporate organization will be presented as follows.

\subsubsection{Memorandum of Association}

The memorandum of association or memorandum (as it is generally known) is sometimes termed the external constitution of the company $[19,20]$. Every club, society or association needs a constitution or set of rules to regulate the way the business of the association is conducted. The registered company is no different and its constitution is contained in two documents, the memorandum of association and the articles of association. Both are filed with the registrar of companies when the company is formed and they remain open for public inspection.

Memorandum of Association (MOA) is a legal document prepared in the formation and registration process of a limited liability company to define its relationship with shareholders. It is accessible to the public and describes the company's name, physical address of registered office, names of shareholders and the distribution of shares [20]. The memorandum of association is a constitution of a company and a corner stone over which company is built. Accordingly, in case of controversy memorandum of association prevails over articles of association. Further, the articles cannot modify any of the contents of the memorandum.

It is the first step in the formation of companies. It contains the fundamental conditions on which the company is to be incorporated. In fact, this document is of great important in relation to the affairs of the proposed company. It may rightly be called a "charter" or the "construction" of the company as it regulates the relationship of the company with the outside world. It also lays down the powers and objects of a company, and the scope of the operations of the company beyond which its actions cannot go. The company is bound to act according to the objects and powers as contained in its memorandum of association. If the company's acts go beyond the provisions of the memorandum, its act will be ultra-virus [21].

Generally memorandum of association is the main documents that address many important issues in relation to company whether it private limited company or share company. From article 211 of commercial code [9] we can easily understand that memorandum of association is a contract that arises from partnership agreements. Accordingly, memorandum of association that fulfills general requirement under article 1678 of Ethiopian civil code [18] and special requirement under commercial code has a binding effect on the contracting parties as it is considered as a law between them. This can be inferred from article 1731 of civil code [18]. Accordingly shareholders can fill the gaps that left by laws on corporate governance of private limited company by incorporating the issues that has not been included under commercial code to either memorandum of association.

\subsubsection{Articles of Association}

Every registered company has to have, in addition to a memorandum, articles of association. This document will contain the basic regulations for the management of the company, covering such matters as the issue and allotment of shares, the calls on shares, the rules relating to the transfer of shares, the procedures to be followed at general meetings and the regulations relating to members voting, the appointment, removal and powers of directors, the payment of dividends and the capitalization of profits [22]. It is the document contains the rules, regulations and bye-laws for the internal management of the company. These rules and regulations are framed for the purpose of carrying out the objects of the company as stated in the memorandum of association. Like that of memorandum of association, an article of association that fulfills general requirement under article 1678 of Ethiopian civil code [18] and special requirement under commercial code has a binding effect on the contracting parties as it is considered as a law between them. Accordingly shareholders can fill the gaps that left by laws on corporate governance of private limited company by incorporating the issues that has not been included under commercial code to article of association.

\subsubsection{Corporate Code of Governance}

Unlike that of the developed countries of the world, our country has no experience of solving corporate issue with corporate code of conduct. Though we may not have an experience of addressing the issues of corporate governance via corporate code of conduct, it does not mean that the business communities are legally prohibited from doing so. Currently, the Ethiopian institute of corporate governance has put an initial inception in initiating and taking a charge of 
developing corporate code of conduct. Though, it may not be a panacea solutions for addressing the overall problem of corporate governance, it has something to do with reducing the perplexities that may emanates from the loopholes that left by corporate legal regime of our country. Ethiopian Institute for Corporate Governance has prepared a code of conduct for share companies. The code, which was launched at a meeting held at Hyatt Regency Hotel on April 18, 2019, covers issues related to the overall activities of share companies [23]. According to Tehtena Legese, board member and managing director of WarytMulutila International Plc, the code is one of the achievements of the institution that can be used as a guideline for companies to form their own corporate governance code [23]. The Institute was launched in 2013 to operate under the Addis Ababa Chamber of Commerce \& Sectorial Associations. The Institute, which so far has enlisted 148 public and private businesses as members, seeks to regulate the conduct of businesses toward the evolution of a dynamic, ethical and responsible business community [23]. Accordingly, Code of corporate governance that developed by voluntary acts of business communities could be a good way out in filling the gaps that left by Ethiopian laws. Hence, every stakeholder should play its own role in enhancing an ongoing attempt towards developing corporate code of conduct which has been undertaking under the auspices of Ethiopian institute of corporate governance.

To this effect, corporate code of conduct for private limited companies should be developed by Ethiopian institute of corporate governance for various reasons. First, compared to share company law, Ethiopian private limited company law has tremendous gaps. Second, since most of the companies in Ethiopia are established in the forms of private limited companies and the Ethiopian laws has left tremendous loopholes, it is quite intricate to ensure the proper regulation of private limited companies. Not only this, the alleged draft on amendment of commercial code of Ethiopia is not yet come into force and it may even takes it a decade to come into an effect. Hence, developing corporate code of conduct for private limited company is of essence.

\subsection{Filling the Gaps of Law of Ethiopian Private Limited Company by Custom}

Custom in law is the established pattern of behavior that can be objectively verified within a particular social setting. Customary law is a recognized source of law within jurisdictions of the civil law tradition, where it may be subordinate to both statutes and regulations. In addressing custom as a source of law within the civil law tradition, john Henry bon man notes that, though the attention it is given in scholarly works is great, its importance is slight and decreasing [24].

Customary law is also used in some third world countries, such as those in Africa usually used alongside common or civil law [25]. For example, in Ethiopia, despite the adoption of legal codes based on civil law in the 1950s according to Dolores Donovan and Getachew Assefa there are more than 60 systems of customary law currently in force, some of them operating quite independently of the formal state legal system [26]. They offer two reasons for the relative autonomy of these customary law systems: one is that the Ethiopian government lacks sufficient resources to enforce its legal system to every corner of Ethiopia; the other is that the Ethiopian government has made a commitment to preserve these customary systems within its boundaries [24].

The Constitution of the Federal Democratic Republic of Ethiopia provides the framework for the independent validity of non-state or unofficial laws such as customary and religious laws in some fields of social activity. Article 34 (5) of the federal constitution provides that, "this constitution shall not preclude the adjudication of disputes relating to personal and family laws in accordance with religious and customary law, with the consent of the parties to the dispute. Particulars shall be determined by law" [27]. Not only this, Article 78 (5) of the same constitution stipulates that, "Pursuant to sub-article (5) of Article 34, the House of Peoples 'Representatives and State Councils can establish or give official recognition to Religious and customary courts that had state recognition and functioned prior to the adoption of the constitution shall be organized on the basis of recognition accorded to them by this constitution".

As can be gleaned from the above cited constitutional provisions, formal legal pluralism under Ethiopia's new constitutional order is confined to certain matters: only personal status and family law. The state legal system, however, carried on to monopolize the public law areas of criminal law, constitutional law, labor/employment law and the like. Only personal law has been singled out for recognition.

Ethiopia's traditional customary legal system is widely used by individuals and small commercial enterprises and is reported to be reasonably efficient. Individuals with commercial disputes often turn first to the customary system (usually the elders of a community or urban neighborhood), then to the courts only if the dispute cannot be resolved. Judges indicate that they review the findings of the elders as if they had come from a lower court. This state of affairs is not necessarily a barrier to the development of a domestic market system. It is, however, a system which will not be viable for business in the international market, and the dependence upon customary dispute resolution will need to be reduced by individuals wishing to enter the global marketplace [24].

Besides, the drafter of Ethiopian commercial code, Escarra remarks that "until now there have not been local commercial customs in Ethiopia. The business practices which came to my attention were generally not very significant. From the aforementioned facts, we can easily understand that, Ethiopia is not as such bestowed with good commercial practices to which the issues of corporate governance of private limited company are not an exception. Hence it is difficult to fill the gaps that left by commercial code on the issues of private limited company by custom.

\section{Conclusion and Way Forward}

Private limited companies are the most popular forms of companies in Ethiopia. Nevertheless, no amendments have 
been made since its birth in 1960 and the gap in private limited company is huge.

In relation to how those gaps may be compromised, the paper has tried to answer whether those gaps can be solved via contract, custom or law. Memorandum and article of association is a contract between a company and its members, and among members themselves. Accordingly, those gaps can be solved via contract by inculcating it into articles or memorandum of association and corporate code of conduct. Yet, while they fill the gaps that left by private limited company laws via articles or memorandum of association, the general requirement for formation of contract as envisaged under civil code and special requirement under the commercial code should be complied with. In relation to custom, since commercial custom on corporate governance is at an infancy stage, it cannot be used as an alternative in filling the gaps that left by private limited company law of Ethiopia. Though, contract can fill the gaps that left by private limited company law of Ethiopia, the panacea solution is amending the existing laws on private limited company in a way that could address the existing practical problems associated with it. On the basis of the aforementioned conclusion, my recommendation includes:

a) Ethiopian government should amend commercial code of Ethiopia as the code that lasts more than 58 years cannot accommodate the commercial transactions of $21^{\text {st }}$ century.

b) Again, until the Ethiopian government amends commercial code, I recommend for the business community to exercise freedom of contract and fill the gaps of private limited companies by addressing it via articles and memorandum of association.

c) Finally, I recommend for Ethiopian institute of corporate governance to take a charge of developing code of corporate governance for private limited companies in similar fashion with that of corporate code of governance for share companies.

\section{References}

[1] Alameyewu Yismawu, "Merits and demerits of introducing non-shareholder directors in the governance of Ethiopian share companies", 2014, unpublished.

[2] Endalewu lijalem, "The doctrine of piercing the corporate veil: its legal significance and practical application in Ethiopia", 2011, unpublished.

[3] Brayan A. Garner, Black's Law Dictionary, West publishing Co, U.S.A, 9th ed, 2009.

[4] Angela Schneeman, The Law of Corporations and Other Business Organizations, USA, 5th ed, 2010.

[5] Charles Wild and Stuart Weinstein, Smith and Keenan's Company Law, Pearson Education Limited, England, 14th ed, 2009.

[6] Dejene Alamerewu, "Assessing corporate governance of Ethiopian private limited companies: with particular emphasis on making board of directors compulsory to such companies", 2013.

[7] Niguse Tadese, "Major problems associated with private limited companies in Ethiopia: the law and the practice”, 2009.

[8] Fekadu Petros, Ethiopian Company Law, Far East Trading, Addis Ababa, 2012.

[9] Commercial Code of the Empire of Ethiopia of 1960, Fed. Neg. Gaz, Extraordinary Issue 19th year, No. 3.

[10] Banking Business Proclamation, No. 592/2008, Fed. Neg. Gaz. 14th Year, No. 57.

[11] Insurance business Proclamation No. 746/2012, Fed. Neg. Gaz, 18th Year, No. 57.

[12] Federal Micro Finance Institutions Proclamation No. 626/2009, Fed. Neg. Gaz, 15th Year No. 33.

[13] Public enterprise proclamations no 25/92, Fed. Neg. Gaz. 22nd Year, No. 20.

[14] Labour proclamation No. 377/2003 of Ethiopia, Fed. Neg. Gaz, 10th year no. 12 .

[15] Trade Competition and Consumers Protection Proclamation No. 813/2013, Fed. Neg. Gaz 20thYear No. 28.

[16] Yared Haile-Mekel, "Revising the Ethiopian Commercial Code", January 2018, available https://www.thereporterethiopia.com/article/revising-ethiopian -commercial-code (accessed on 28/07/2019).

[17] Mulugeta M. Ayalewu, "commentaries on Ethiopian law of contracts', 2010.

[18] Civil Code of the Empire of Ethiopia, Proclamation No 165/1960, Fed. Neg. Gaz, 19th Year No. 2.

[19] Professor Nicholas Bourne, Essential company law, Cavendish publishing limited, London, third edition, 2000.

[20] Paul Merchant; definition of memorandum of association, Updated February2019, available at https://smallbusiness.chron.com/definition-memorandum-asso ciation-17475.html (accessed on September 23, 2019).

[21] Almineh shinashawu, "The nature and scope of private limited company in Ethiopia; the law and practice; focus on bankruptcy", 2008.

[22] Simon Golding, company law, Cavendish publishing limited, second edition, 1999.

[23] Addis fortune news, "Ethiopian institute of corporate governance establish corporate code of conduct for share companies", April 20, 2019, available at https://addisfortune.news/institute-establish-code-of-conduct/( accessed on august, 2019).

[24] Merry man, John Henry (2007). The Civil Law Tradition: An Introduction to the Legal Systems of Europe and Latin America (3rd ed.).

[25] Jury globe, university of Ottawa, world legal system research group, available at http://www.juriglobe.ca/eng/(accessed on August 2019).

[26] Dolores A. Donovan and Getachew Assefa (2003). Homicide in Ethiopia: Human Rights, Federalism, and Legal Pluralism, American Journal of Comparative Law.

[27] Constitution of federal democratic republic of Ethiopia, 1st year no 1, August 1995. 